\title{
Yeni Türkiye Devletinin Temel Değerleri'nden Egemenlik-Millet Unsuru ve Atatürk
}

\author{
Yard. Doç. Dr. Nuri YAZICI
}

\begin{abstract}
ÖZET
Bu makalede bir Türk devleti sona ererken yeni bir Türk devletinin kuruluşu incelenmiştir. Bu dönüşüm yalnız siyasî yapıda olmamış, Türk toplumu ve devleti yüzyılların tecrübeleri ve çağdaş ihtiyaçların ışı̆̆ında yeniden yapılanmıştır. Yani teokratik - monarşik bir yapıdan millî - lâik - demokratik bir yapılanmaya geçiş görülmüştür. Bu geçiş döneminde devletin toprak, insan ve egemenlik unsurlarındaki değişim incelenmiștir. Bu değișimin yanı sıra Anadolu'ya yönelen işgal ve istilâya karşı da bir Istiklâl Savaşı sürdürülmüştür. Makalede, bu tarihsel kesitin iki yanına vurgu yapılmakla beraber, asıl bu büyük siyasal ve toplumsal değişim ele alınmıştır; imparatorluktan millî devlet yapısına geçiş ve inkılaplarla millî devlet ve millî toplum kurma politikalarının nasıl gerçekleştirildiğ i incelenmiştir.
\end{abstract}

\section{Sovereignity - Nation Factor As The Fundamental Principles Of New Turkish State And Atatürk}

\section{ABSTRACT}

In this article, the formation of a new Turkish state is examined while an other Turkish state was coming to its end: this tranformation did not only take place in the political structure, but also Turkish society and state has been restructured in the light of the past experiences lasting for centuries and the necessities of the modern age. In other words, a transformation from theocratic-monarchic structure into a national - secular - democratic one was observed. In addition to this major change, the Independence War had been conducted against the invasion of and attacks towards the Anatolia.

\footnotetext{
· Selçuk Üniversitesi Eğitim Fakültesi Öğretim Üyesi.
} 
In this article, while the two sides of this historical period are being emphasised, more than that this major political and social change is investigated. The transformation of an empire into a nation - state and reforms are examined as well as the structuring of the polities of nation state and national society.

Türkler tarihte siyasî devamlılık gösteren bir millet olarak temayüz etmişlerdir. Çeşitli nedenlerle anayurtlarından çok uzaklarda hâkim bir millet ve devlet olarak yaşamışlardır. Bu kuruluşlar ve yükselişler çağdaş şartlardan ve millî tecrübelerden etkilenmiş, yeni Türk devletleri ortaya çıkmış ve bağımsız devlet geleneği sürdürülmüştür. İ̉şe 19. yüzyılın sonları ile 20. yüzyılın başları da böyle bir değişime ve bağımsız devlet geleneğinin sürdürülmesi mücadelesine sahne olmuştur.

17. yüzyıldan itibaren çağdaş değişimlere ve kendisine yönelik yıkıcı politikalara karşı gittikçe dayanma gücünü kaybeden Osmanlı Devleti bir bunalım dönemine girmiştir. Bu değişim ihtiyacı nihayet devletin omurgası sayabileceğimiz temel siyasî değerlerine dayanmış, çok uluslu teokratik monarşik devlet dağılmaya başlamıştır. 20. yüzyılın başlarında ise, artık "millî hayatı hitâm bulmuş farz edilen büyük millet" bağımsızlık mücadelesi vererek, "ilmin ve fennin en son esaslarına dayalı millî ve asrî..." bir devlet kurmuştur. Bu süreci anlatan Mustafa Kemal Atatürk, "Bugün vâsıl olduğumuz netice, asırlardan beri çekilen millî musibetlerin intibahı ve bu aziz vatanın her köşesini sulayan kanların bedelidir." demiştir.'

Aslında sona eren Osmanlı Hanedanı'nın saltanatıydı; hanedan merkezli, çok uluslu teokratik - monarșik yapı dağılmaktaydı. Osmanlı Devleti'nin bu temel siyasî değerleri şimdi ilim ve fennin, geçen yüzyıllarda yaşanan tecrübelerin ışığında değişime uğramakta, "Osmanlı Devleti'nin külleri..." arasından millî ve çağdaş bir Türk devleti doğmaktaydı.

\section{A) Millî Mücadele öncesi}

Osmanlı Devleti'nde 17. yüzyıldan itibaren görülen 1slâhat geleneği, II. Mahmut döneminde devletin ve toplumun her katına yayılan bir reform özelliği göstermiștir. Bu reform anlayıșı daha sonra da devam etmiş ve bir zihinsel değiş̧ime, batılı görüşe sahip kimselerin yetişmesine, Batı zihniyetini aksettiren bir akımın doğmasına yol açmıştır. Gülhane Hatt-1 Hümayunu ve Islâhat Fermanı ile devam eden bu süreç Meşrutiyet'e varmıştır. Bu değişimin öncüleri olan Genç Osmanlılar, "batıda demokratik mücadele safhasından geçerek meşrutiyet idaresine kavuşmuş devletlerin idaresine benzer bir idare istemişler"dir. ${ }^{2}$ Kanun-1 Esasî bu gelişmenin tarihî, sosyal, fikrî ve siyasî sonucu olmuştur. Tanzimat'tan itibaren gelişerek Meşrutiyet'e uzanan bu hareket "Osmanlılık" denilen siyasî bir doktrine

I Kemal Atatürk, Nutuk (1919- 1927), Ankara 1989, s: 596.

2 Enver Ziya Karal. Osmanlı Tarihi VIII. Cilt, Ankara 1962, s: 228. 
dayanıyordu. Bu siyasal doktrin, "cins ve mezhep farkı gözetilmeksizin, halkı devlet idaresine iştirak ettirmek, aynı zamanda mümkün olduğu kadar bu idare üzerinde bir halk murakabesi kurmak, bu suretle de imparatorluktan ayrılmak isteyen teb'ayı menfaat bağlarıyla bağlayıp imparatorluğun mukadderatı ile ilgilendirmek." ${ }^{3}$ biçiminde tanımlanabilir. Bu anlayışı esas alan Kanun-1 Esasî'ye göre de, Osmanlı Devleti'nin tabiiyetinde bulunan herkesin Osmanlı olduğu, kişisel hürriyetlerine sahip bulundukları, din ve mezhep işleri dışında kanun önünde hak ve yükümlülükler yönünden eşit oldukları tespit edilmişti.

Gülhane Hatt-1 Hümayunu ve Islâhat Fermanı'yla teb'anın eşitliği tanınmışsa da, bu tek taraflı olarak padişahın taahhüdü niteliğinde idi. Ayrıca bu belgeler, din ve mezhep esasına dayanan "cemaat" teşkilâtını bir siyasî değer olarak kabul etmekte, halkın devlet idaresinde reyini tanımamakta ve halk için Osmanlı Hanedanından başka bir kıymet veya müessese kabul etmemekte idi. ${ }^{4}$ Kanun-1 Esasî ise, teb'a ile padişah arasında bir sözleşme olup, seçim unsuru ile halkın yönetime katılımını sağlamakta idi. Fakat bu duruma bakarak da, "Kanun-1 Esasî’nin muhteva itibariyle millî hakimiyet prensibini kurmuş olduğu söylenemez." ${ }^{5}$ Çünkü aynı anayasa ile Hükümdar'a çok geniş yetkiler tanınmış, üstün irade padişah iradesi olmuştur. Çeşitli din ve inançlara sahip, imparatorluğa değişik zamanlarda katılmış, ayrı ayrı soylardan ve kültürlerden meydana gelen teb'adan bir millî hakimiyet kavramı da doğamazdı.

19. yüzyılın sonlarına doğru bu siyasî mirası "Genç Türkler" devraldı. Gerçi onların batı basınında bu adla adlandırılmaları kendi aralarında da rahatsızlık yaratıyordu. Çünkü bu büyük değişim sürecini etkileyen en önemli gelişme Fransa İhtilali'nin getirdiği yeni fikirlerdi: “1789 Fransa İhtilali sayesinde, teorik olarak ileri sürülen görüşlerin pek çoğu uygulama alanına intikal ettirildi. Bunun sonucu devlet hukukîleşti, hakimiyetin kaynağı sosyalleşti, toplum (halk) milletleşti, toprak (coğrafya) vatanlaştı. Özellikle, millet kavramının ortaya çıkması neticesinde halk yığınlarının milletleşmesi zarurî olarak millî devlet, millî hakimiyet, millî irade, millî coğrafya gibi kavramları gündeme getirdi." Sırp ve Yunan isyanları, bu nedenlerle Osmanlı siyasî yapısını zorlamışsa da, asıl 1877-1878 Osmanlı-Rus Savaşı, "Osmanlılık" fikrini büyük ölçüde zayıflatmıştır: "Bu harb esnasında, Balkanlarda Osmanlı hakimiyetinde yaşayan Hristiyanların Müslümanları katletmeleri, Balkanlarda ve Doğu Anadolu'da ilerleyen Rusların Hristiyanlığın koruyucusu pozunu takınmaları, Rumlanı ve Ermenileri de tahrik etmeye başlamaları, İmparatorluğun Müslüman halkında Hristiyanlara karşı sert bir tepki yaratmıştır."

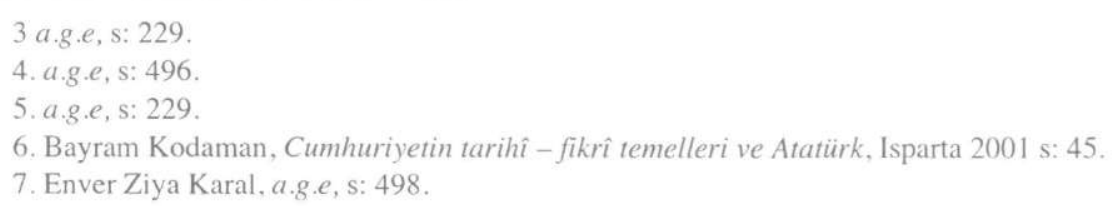


süre için aksattı ve Balkan Savaşları da Osmanlılık fikriyatının sonunu getirdi; “Osmanlı İmparatorluğu'nun, bir bütün olmayıp, zayıf bir merkez etrafında toplanmış bağımlı ve kısmen bağımlı sınır ülkelerinden meydana gelen bir devlet olduğunu ortaya koydu." ${ }^{\circ}$ Netice olarak var olan milliyetler, olması istenen Osmanlı milliyetini yendi.

“'Osmanlı İmparatorluğu'nda Müslüman-Hristiyan münasebetlerinin kötüleşmesi, Avrupa'nın, Osmanlı Hristiyanları lehinde müdahaleleri, İmparatorlukta ve dünyada İslâm memleketlerinin Avrupalılar tarafından istilâsı, İslâm dünyasında İslâm ittihadı lehinde fikir cereyanlarının belirmesi"9 Osmanlı Devleti'nde "İslâmcılık" politikalarının ortaya çıkmasına zemin hazırladı. Bu politikalar içte Arap kökenli yöneticilerin üst makamlara getirilmesi ve Arap kültürünün üstün tutulması biçiminde kendini göstermeye başladı. Türkçe'nin resmî dil olması daha Tanzimat döneminde gündeme gelmiş olmasına rağmen ${ }^{10}$, bu dönemde devrin padişahı II. Abdülhamit, İmparatorluğu bir Türk-Arap İmparatorluğu haline getirmeyi, Türkçe'nin bırakılıp, yerine Arapça'nın getirilmesini düşünmüştür." Bu politika döneminde "Hilafet" kurumu daha da öne çıkmıştır. Çünkü İslâmcılık politikasının dış politika yönü bu kurumun önemini artırmaktadır: Böylece Osmanlı padişahının, dünyevî otoritesinin yanında bir de ruhanî otorite sahibi olduğu görülmekte ve bu kimliğiyle sadece Osmanlı toplumunun siyasal birliğini sağlamak değil, bütün dünya Müslümanlarının siyasî lideri olacağı düşünülmektedir. Bu politikalarla, "Müslüman topraklar üzerinde hakimiyet kurmuş olan İngiltere, Fransa, Rusya ve Hollanda, Halife'nin tesiri altına girecektir. Çünkü Halife'nin bir kelimesi ile cihat başlayacak ve bütün Müslümanlar bir tek vücut gibi ayaklanıp gâvurların idaresinden kurtulacaklardır."'12

Adı II. Meşrutiyetle özdeşleşen İttihat ve Terakki Cemiyeti bu politik tecrübeleri yaşayan siyasî bir ekip olduğu halde İmparatorluğun toplumsal yapısı sebebiyle Osmanlılık ve İslâmcılık/Ümmetçilik politikalarına sarılmıştı. Bütün Osmanlıların birliğini sağlamak gibi bir hedefe yönelmişti. Bununla beraber yayımları yoluyla halka mal etmeye çalıştığı fikirleri arasında, "Türklük şuurunun uyandırılması gereği”" de vardı. ${ }^{13}$ Yayımlarında, halka hitap edişlerinde de, Osmanlı halkının özelliği ve temayülü dikkate alınarak Osmanlı, İslâm, Türk kelimeleri bir siyasî terim olarak kullanılıyordu; "Arap ekseriyeti ile meskûn bölgeler halkına "Müslümanlar", Türklerin Hıristiyanlarla karışık bulunduğu bölgeler halkına "Osmanlılar" yalnız Türklerin bulunduğu bölgeler halkına da "Türkler" diye hitap

\footnotetext{
8. İlter Turan, Cumhuriyet Tarihimiz, İstanbul 1969, s: 26.

9. Enver Ziya Karal, a.g.e, s: 540.

10. Enver Ziya Karal, a.g.e., VII. Cilt, Ankara 1977, s: 292.

11. Enver Ziya Karal, a.g.e., VIII. Cilt, Ankara 1962. s: 545.

12. a.g.e, s: 546 .

13. a.g.e, s: 523.
} 
edilmiştir." ${ }^{14}$ Fakat, İttihat Terakki Fırkası, 1916 Kongresi'yle beraber, "Osmanlıc1" ve "İttihad-1 Anasır"cı (İmparatorluğu oluşturan etnik unsurları kaynaştırıc1) bir ideolojiden milliyetçi (Türkçü) ve lâik bir plâtforma" geçmiştir. ${ }^{15}$ Bu Kongre'de hukuk ve adalet örgütü alanında lâiklik ilkesi kabul edilmiştir.

İslâmcılık/Ümmetçilik politikaları, I. Dünya Savaşı'ndan başarısızlıkla çıkmıştı... Bir taraftan bu etkiyle, bir taraftan da Osmanlı teb'ası içinde yer yer yoğun olarak gayrimüslimlerin bulunması sebebiyle, "tarafsız", doğru, dolayısıyla lâik ve meşrutî bir idare..."16 konuşulup tartışılmaya başlanmıştır.

Osmanlılık ve Ümmetçilik tecrübeleri, Hristiyan toplulukların ve Türk olmayan Müslüman toplulukların İmparatorluktan ayrılma temayülleri ve Türklük aleyhindeki tavırlar ve politikalar, bahsedilen bu siyaset taraftarlarını da bir süre sonra Türkçü bir fikir etrafında toplanmaya yöneltmiştir. Zaten 20. yüzyılın başlarından itibaren yaşayan olaylar da, Türklerden başka hiçbir milletin, devleti benimsemediğini göstermektedir.

Türkçülük siyasal bir şekil olmaktan çok kendini dil, edebiyat ve tarih alanlarında göstermiştir... Bir ara Turancılık politikaları da görülmüşse de I. Dünya Savaşı, bu politikayı da tasfiye etmiştir.

19. yüzyıldan itibaren Osmanlı İmparatorluğu dağılırken, kaybedilen topraklardan çekilen Türk halk, Anadolu'da millî bütünlüğü güçlendirmeye başlamıştı... Böylece millî mücadelenin ve millî devletin tarihsel zemini ortaya çıkmıştır.

Mustafa Kemal Atatürk bu politikalar için şu analizi yapıyordu: "Efendiler, büyük ve hayalî şeyleri yapmadan yapmış gibi görünmek yüzünden bütün dünyanın husumetini, garazını, kinini bu memleketin ve bu milletin üzerine celbettik.. Biz Panislâmizm yapmadık. Belki (yapıyoruz, yapacağız) dedik. Düşmanlar da (yaptırmamak için biran evvel öldürelim) dediler. Panturanizm yapmadık (yaparız, yapıyoruz dedik, yapacağız dedik) ve yine (öldürelim) dediler. Bütün dava bundan ibarettir."17 Yine Atatürk'ün Panislâmizm/Ümmetçilik siyasetine yönelttiği eleştiri de şu olmuştur: "Halifeye, dünyaya meydan okumak ve onun umum İslâm umuruna tasarruf sahibi kılmak fikrinde olanlar, bu vazifeyi yalnız Anadolu halkından değil, onun sekiz on misli nüfustan mürekkep olan büyük İslâm kütlelerinden talep etmelidir. Yeni Türkiye halkının, artık kendi hayat ve saadetinden başka düşünecek bir şeyi yoktur." ${ }^{18}$ Mustafa Kemal Atatürk, bu sözleriyle Türk ve İslâm dünyasının sorunlarına yabancılaşmayı anlatmıyor, ancak Osmanlı'nın

14. a.g.e, s: 523 .

15. Tarık Zafer Tunaya. Türkiye'de Siyasal Partiler, C: I (İkinci Meşrutiyet Dönemi) İstanbul 1984, s: 28 ve 31 .

16. Enver Ziya Karal, a.g.e, s: 550 .

17. Enver Ziya Karal, Atatürk'ten Düşünceler, İstanbul 1981, s: 130.

18. a.g.e, s: 77 . 
bu politikalarının Türk milletinin kaynaklarını tükettiğini görüyor ve siyaseten gerçekçi hedeflere yöneliyordu. Nitekim, onun "Bugün esaret acıları altında inleyen birçok dindaşlarımız vardır. Bunlar için de, kendi muhitlerinde bağımsızlıklarını kazanmaları ve tam bağımsızlık ile memleketlerinin refah ve yükselmesine gayret sarf etmeleri en büyük temennilerimizdendir." 19 sözleri bu kanıyı doğrulamaktadır.

\section{B) Millî Mücadele dönemi}

I. Dünya Savaşı tecrübesi, Türk askerinin Anadolu'dan çok uzakta, "Türk olmayan komutanlar elinde bir hayal uğrunda israf edilmesine" ${ }^{20}$ karşı çıkan, Anadolu'nun elde tutulması gerektiğine ve devleti yönetenlerin, "Trakya ve Anadolu'ya, esas Türk vatanı addıyla Osmanlı ûmran ve servetini bu hudut içerisinde...."21 toplaması gerektiğine inanan bir asker aydın grubu ortaya çıkarmıştı. Artık, imparatorluğu mevcut sınırları içinde korumanın imkânı kalmamıştı. Mustafa Kemal Paşa, henüz yüzbaşı iken, Selânik'te bu tartıșmaların yapıldığ 1 bir ortamda, elindeki kalemiyle Osmanlı İmparatorluğu'nun kabataslak bir haritasını çizer. Selânik ve Hatay'dan bir çizgi çekerek, "Burası bize yeter..." der ${ }^{22}$ yeni Türk devletinin sınırları, yani Misak-1 Millî yaklaşık olarak görülmüştür... İmparatorluk topraklarının bu derece tasfiyesinin, bu büyük yıkımın saltanat ve yönetim şekli üzerinde de etkilerini göstermesi doğaldır. Bahsedildiği üzere 19. yüzyıl başlarından itibaren gelişen bir toplumsal değişim süreci de vardı... Bu bakımdan Millî Mücadele dönemi işgal ve istilâya son vermek mücadelesi yanısıra topyekün bir değişimi ve kuruluşu da beraberinde getirecektir.

Mondros Mütarekesi'nden sonra Anadolu'da yer yer bir direniş başlamışsa da, bunun bütün Anadolu'ya ve millete mal edilmesi Mustafa Kemal Atatürk'le olmuştur; Amasya Genelgesi'nin, "vatanın bütünlüğü, milletin istiklâli tehlikededir." şeklindeki birinci maddesi hem içinde bulunulan durumu belirtmekte, hem de genelgenin yayımlanma sebebini açıklamaktadır. Artık buradaki "vatan" ve "millet" kavramları, imparatorluk dönemindeki içeriğinde değildir. Genelgenin diğer maddesinde ise, "milletin istiklâlini yine milletin azm ü kararı kurtaracaktır." denilerek "millî iradeye" işaret edilmiştir. Ayrıca bu iradenin nasıl belirleneceği de yine genelgede, "muktedir ve milletin itimadına mazhar..." kişilerin seçilmesi suretiyle olacağ ${ }_{1}$ şeklinde belirtilmişti. ${ }^{23}$ Adeta, halka "millî hakimiyete dayalı, kayıtsız şartsız bağımsız yeni bir Türk devleti kurmak."24 mesajı veriliyordu.

19- Utkan Kocatürk. Atatürk'ün Fikir ve Düsünceleri, Ankara 1999, s: 25.

20- "Atatürk", md, islâm Ansiklopedisi, C: I, s: 762.

21- Cemalettin Taşkıran, Millî Mücadele'de Kâzım Karabekir Pașa, Ankara 1999, s: 20.

22- Afif Büyüktuğrul, 18 Mart Çanakkale Zaferi ve Atatürk, Milliyet Gazetesi, 18 Mart 1974, s: 2 .

23- Kemal Atatürk. Nutuk-Vesikalar, Ankara 1991, s: 627, Vsk: 26.

24- Kemal Atatürk, Nutuk (1919 - 1927), Ankara 1989, s: 113. 
Erzurum ve Sivas Kongrelerinde de, doğrudan Saltanat ve Hilafet hedef alınmaksızın, millî iradenin hakim kılınmasının esas olduğu belirtilmiştir. ${ }^{25}$ Ayrıca toprak bütünlüğü savunulan vatanın sınırlarının, 30 Ekim 1918 Mondros Mütarekesi imzalandığındaki sınırlar olduğu da her iki kongrenin ortak kararıdır. Yine iki kongrede de kurulan, ancak Sivas Kongresi'nde yetkileri genişletilen Temsil Kurulu'nun varlığı da, Anadolu'da artık Türk milletini temsil eden yeni bir siyasî iradenin doğduğunu göstermektedir.

$\mathrm{Bu}$ gelişmeler Anadolu'da, "millî hakimiyet" iradesi etrafında bir kurumlaşmanın olduğunun kanıtıdır; "Kuvva-i Millîye" artık bir "Kuvva-i siyasiyye" haline gelmektedir. Gelişen olaylar birbirini bütünlemektedir ve siyasî bir değişimin de habercisidir. Nitekim Mustafa Kemal Paşa, Osmanlı saltanat yönetiminin memleketin kurtulmasına ve kalkınmasına kâfi gelmeyeceği kanaatindeydi: Erzurum Kongresi öncesinde, yakın çevresine bir konuşma sırasında, "Açıkça söyleyeyim, hükümet şekli zamanı gelince Cumhuriyet olacaktır." demişti. ${ }^{26}$ Bundan sonrası bir zaman ve uygulama meselesiydi. Bu hedefi, en başta açıklamak siyasetin doğasına aykırı idi. Bu nedenle, yine Mustafa Kemal Atatürk'ün ifadeleriyle, "Tatbikatı bir takım safhalara ayırmak ve vakayi ve hadisattan istifade ederek milletin hissiyat ve efkârını izhar eylemek ve kademe kademe yürüyerek hedefe vâsıl olmaya çalışmak lâzım geliyordu."27

Erzurum ve Sivas Kongreleri'nin ortak kararlarından biri de "Meclis-i Millı̂"nin toplanması idi; "Milletlerin kendi mukadderatlarını bizzat tayin ettiği bu tarihî devirde hükümet-i merkeziyemizin de irade-i millîye'ye tâbi olması zaruridir." denmekte, millî iradeye dayanmayan hükümetlerin kararlarının içte ve dışta geçerli olmayacağı belirtilmekte idi. Yani kongre kararlarıyla bir millî devletin ana unsurları belirlenmiştir; millî sınırlar, milletin kendi kaderini kendisinin tayin etme hakkı ve toprakları üzerinde mutlak egemenlik... Ayrıca kongrelerin, devamlılığını bir temsil kuruluyla sağlamış olması mücadelenin bir önderler heyeti tarafından yürütüleceğini ortaya koyuyordu. Bu nedenlerle artık Anadolu'da, Saltanat'in kaldırılışına kadar süren bir siyasal mücadele başlayacaktır. Türk milletini temsil iddiasından kaynaklanan bu mücadelenin taraflarından biri olan İstanbul Hükümeti meşruîyetini saltanattan ve "irade-i seniyye"den, Temsil Kurulu ise meşruîyetini Sivas Kongresi'nden ve burada tecelli eden "irade-i millîye"den almaktaydı.

12 Eylül 1919 günü Damat Ferit Paşa Hükümeti ve İstanbul ile her türlü irtibatın kesilmesi ve ardından 13 Eylül 1919 genelgesiyle Anadolu'da seçim hazırlıklarına girişilmesinin istenmesiyle bu siyasal mücadelenin ilk perdesi

25. Bekir Sitk1 Baykal (Yay.Haz.), Erzurum Kongresiyle ilgili belgeler, Ankara 1969, s: 24, Uluğ Ĭğdemir, Sivas Kongresi Tutanakları, Ankara 1986, s: 113.

26. Mazhar Müfit Kansu, Erzurum'dan ölümüne kadar Atatürkle beraber, 1. Cilt, Ankara 1986, s: 74

27. Kemal Atatürk, a.g.e, s: 10. 
açılmıştır. Nitekim bu genelge Anadolu'da yer yer merkezî hükümete, Saltanat'a ve Hilâfet'e başkaldırmak, Anadolu'da geçici bir yönetim kurmak biçiminde algılanmış ve bazı tepkiler de görmüştür. ${ }^{28}$ Mustafa Kemal Atatürk ise, bu girişiminin gerekçesini, memleketi günlerce mercisiz bırakmamak olarak açıklıyordu. Bu gelişmelerin genel istikâmetinin millî hakimiyete dayalı bir devlet olduğu görülür. Yani otorite ve otoritenin kaynağı el değiştirmektedir. Ancak Mustafa Kemal Paşa'nın stratejisine göre, zamanı geldikçe ve parça parça uygulamaya konularak...

Yeni İstanbul Hükümeti'ni kurmakla Ali Rıza Paşa'nın görevlendirildiği 2/3 Ekim 1919 akşamı Mustafa Kemal Paşa tarafından bir genelge ile Türk halkına duyurulmuş ve yeni kabineye Erzurum ve Sivas Kongresi'nin kararlarına ve milletin maksadına riayet ettiği sürece destek olunacağı bildirilmişti. Ayrıca yeni hükümetten, millî meclisin toplanıp fiilî denetime başlayıncaya kadar, milletin geleceği hakkında bir taahhüde girişmemesi istenmekteydi. ${ }^{29}$ Böyle bir ikazın siyasal gücü de millî iradeyî temsil iddiasından gelmekteydi. Nitekim Mustafa Kemal Paşa, 5 Ekim 1919 tarihli Saltanat Makamı'na çekilen telgrafta İstanbul Hükümeti'nin bu siyasal noksanına işaret ediyor ve Meclis'in, 21 Aralık 1918'de feshinden sonraki dört ay içinde toplanması gerektiğini hatırlatıyordu. ${ }^{30}$

Bu siyasal gelişmelerin istikâmeti sadrazam Ali Rıza Paşa tarafından görülmüş gibidir: Çünkü yeni Sadrazam, Ahmet İzzet Paşa'yı bir ziyareti sırasında Mustafa Kemal Paşa hakkında konuşurlarken; "Cumhuriyet yapacaklar, Cumhuriyet!" der. ${ }^{31}$ Osmanlı saltanatının bu cumhuriyet korkusu aslında yeni değildi: II. Abdülhamit de, Mithat Paşa'nın cumhuriyet ilân etmek istediğinden endişe ediyordu. ${ }^{32}$

Amasya Görüşmeleri ve Amasya Protokolleri'nin imzalanması Temsil Kurulu lehine önemli bir siyasal gelişmedir; böylece iç politikada Temsil Kurulu'nun yasal bir teşkilât olarak tanınması sağlanmış ve Türk halkını temsil gücü artmıştır.

Misak-1 Millî'nin, Osmanlı Mebuslar Meclis'inde kabulü, İstanbul Hükümeti'nin politik bir yenilgisidir. Zaten Hükümet, Misak-1 Millî'yi gerçekleştirmek gücünden ve isteğinden de yoksundur. Bu nedenlerle ortaya çıkan bunalım İtilâf Devletlerinin müdahaleleri, İstanbul'un işgali, hükümetlerin istifası, nihayet Meclis'in feshiyle (11 Nisan 1920) son bulur. Bu olaylar Mustafa Kemal Paşa'yı ve Temsil Kurulu'nu, millî iradeyi güçlü bir șekilde temsil etme konumuna getirmiştir: İstanbul'un işgalini izleyen günlerde, 19 mart 1920'de Ankara'da, "olağanüstü yetkilere sahip" bir

\footnotetext{
28. a.g.e., s: 95- 98 .

29. a.g.e, s: 130 .

30. Kemal Atatürk, Nutuk - Vesikalar, Ankara 1991, s: 769. Ves: 132.

31. Kemal Atatürk, Nutuk (1919 - 1927), Ankara 1989, s: 156.

32. Enver Ziya Karal, a.g.e., VIII. Cilt. Ankara 1962, s: 504.
} 
meclisin toplanmasının kararlaştırıldığı duyurulmuştur. Mustafa Kemal Paşa, toplanacak bu meclisi, ilk yazdığı müsveddede, "meclis-i müessisan" adıyla toplantıya çağırmayı düşünmüştür. Bunun da nedeni, yine kendi ifadesine göre, “...toplanacak meclisin rejimi değiştirmek yetkisiyle ilk anda mücehhez bulunmasını temin etmek idi. ${ }^{\prime 33}$ Söz konusu genelgenin birinci maddesinde de, toplanacak olan meclisin görevi, “... umur-1 milleti tedvir ve murakabe etmek.." olarak tanımlanmıştı. Yani bir devlet olmanın şartlarından olan egemenliği temsil ve kullanma gücü mecliste toplanmakta idi. Meclis, milletin vekillerinden oluşmakta, gücünü millî iradeden aldığı için millî hakimiyetin tecelli ettiği bir müessese durumundadır. 23 Nisan 1920 'den itibaren bütün milletin, mülkî ve askerî makamların mercî̂'nin Meclis olacağ 1 tamim edilmiş ${ }^{34}$, Ankara da bağımsız Türk devletinin fiilî başkenti durumuna gelmiştir. ${ }^{35}$ Meclis'i en yaşlı üye sıfatıyla açan Sinop Milletvekili Şerif Bey de açış konuşmasında, “... ulusumuzun iç ve dış tam bağımsızlık içinde alın yazısının sorumluluğunu doğrudan doğrudan yüklenip kendi kendisini yönetmeye başladığını tüm cihana ilân ederek Büyük Millet Meclisi'ni açıyorum.” diyordu. ${ }^{36}$

TBMM, 24 Nisan 1920 'de aldığ 1 kararlarla yetkilerini ve organları belirlemiş, Saltanat'ın da konumunu tayin etmiştir. Padişah-Halife içinde bulunduğu zor ve kötü durumdan kurtulduğu zaman Meclisin tanzim edeceği yasal esaslar çerçevesinde vaziyetini alır denilmiştir ${ }^{37}$ Görüldüğü gibi, saltanatın geleceği Meclis'in iradesine bağımlı hâle getirilmiştir. Gelişmelerin genel istikâmeti ülkede artık siyasal egemenliğin tanımının ve temsilinin el değiştirdiği yönündedir... Nitekim Mustafa Kemal Paşa da, bu noktaya işaret ederek, bu yeni esaslara dayalı yönetim ve hükümetin "millî hakimiyet" esasına dayanan bir halk hükümeti olduğunu, yönetim şeklinin de cumhuriyet olduğunu belirtir. ${ }^{38}$ Bazen açık bazen kapalı bir biçimde belirtilen bu temel siyasî ilkeler 20 Ocak 1921 Anayasasına da girerek, birinci maddede, "Hakimiyet kayıtsız şartsız milletindir. İdare usulü halkın mukadderatını bizzat ve bilfiil idare etmesi esasına müstenittir." biçiminde ifadesini bulmuştur. Yürütme ve yasama gücü de Meclis'in yetkileri arasındaydı. Anayasa'nın üçüncü maddesinde ise, "Türkiye Devleti, Millet Meclisi tarafından idare olunur ve Hükümeti, "Büyük Millet Meclisi hükümeti" unvanını taşır." denmekteydi. Yeni devletin adının ne olacağı meselesi de böylece halledilmiş oluyordu; yeni devletin adında "Türk" kelimesi bulunmaktaydı. "Türkili" veya "Türkistan" olabilirdi. Fakat her iki isim de Pan-Türkist ilişkiler ifade eder düşüncesiyle terk edildi ve uzun

\footnotetext{
33. Kemal Atatürk, a.g.e, s: 281

34. a.g.e, s: $288-289$.

35. Bernard Lewis, Modern Tiükiye'nin Doğuşu, Ankara 1984, s: 251.

36. Yahya Akyüz ve diğerleri. Atatürk Ilkeleri ve Inkılâp Tarihi I/1, Ankara 1997, s: 92.

37. Kemal Atatürk, a.g.e, s: 293

38. a.g.e. s: 293.
} 
zamandır batıda kullanılan "Türkiye" terimi yeni devletin adı olarak kullanıld.$^{39}$

Böylece Anadolu'da "millî hakimiyet" esasına dayanan yeni Türk devleti doğmuş oluyordu: "Büyük Millet Meclisi'nin açılmasıyla birlikte, ulusal egemenlik fikrinin meşruluğu tartışılmaz bir biçimde ortaya konuyordu. Mustafa Kemal Paşa'nın genç bir yüzbaşı iken düşündüğü "yeni bir Türk devleti" de gerçekleşiyordu. "Egemenlik kayıtsız şartsız ulusundur." hükmü yeni Türk devletinin egemenlik kaynağını halktan alan, insan hakları esaslarına dayandırıyordu. 23 Nisan 1920'de egemenlik İstanbul'dan Ankara'ya (Saltanat'tan ulus'a) geçmekle kalmıyor, egemenliğin kaynağı ve yapısı da değişiyordu. Dinsel ve geleneksel Osmanlı egemenliği yerine ulus egemenliği geçiyordu."

Otoritenin (yeni hükümetin) kurulabilmesi ve güçlenebilmesinin önemli bir aşaması da, yeni otoritenin diğer devletler tarafından da tanınmasıdır. İçte yeni Türk devleti kurulması süreci gelişirken, bu oluşumunun askerî ve siyasî alanlardaki başarılarıyla dışta da safha safha tanınması gerçekleşmiştir.

Yeni Türk devletinin dış politikadaki ana hedefi Sevr'i yıkmaktı. Sadrazam Tevfik Paşa'nın da tanımıyla, "İstiklâl ve hatta devlet mefhumlarıyla katiyen kabil-i telif görülemeyen..." ${ }^{41}$ bu anlaşmanın kabul edilmesi için Osmanlı İçişleri Bakanı Reşit Bey’e verilen notada da, "Eğer Osmanlı Hükümeti anlaşmayı imzalamaktan çekinir ve hatta imzaladıktan sonra Anadolu'da anlaşma koşullarını uygulamakta yetersiz kalırsa İtilâf Devletleri bu kez kesinlikle Türkleri Avrupa'dan atmak görevini yerine getireceklerdir." denilmekteydi. ${ }^{42}$

Askerî œephelerdeki başarılar, bunların arkasından Londra Konferansı'nın toplanması (21 Şubat-12 Mart 1921), TBMM Hükümeti'nin bu konferansa ayrıca çağırılarak katılması, Ankara Hükümeti'nin Batılılarca, 'bir kuvve-i meşru-1 millîye" olarak tanındığını göstermektedir. ${ }^{43}$ Loyd George da, Londra Konferansı'nın açıș nutkunda, "Sevres Anlaşmasının imzalanmasından beri Mustafa Kemal Paşa'nın kumandasındaki önemli kuvvetler, bu anlaşmaya karşı koymak için harp ettiler ve bunun sonucu olarak karşılıklı bir anlaşma ile barışı yeniden kurma yolunda ileri sürülen arzuya uyarak bu konferans toplandı." ${ }^{44}$ demek suretiyle İstanbul Hükümeti'nin Türk milletini temsil etmek hususunda Batı basınında çıkan şüphelere hak verdiğini, Sevr'in önündeki siyasî ve askerî engelin kim olduğunu, Türk halkını temsil gücünün kimde olduğunu gösteriyordu... İtilâf Devletleri asıl kiminle anlaşmak zorunda

\footnotetext{
39. İlter Turan, a.g.e, s: 118.

40. Ergün Aybars, Türkiye Cumhuriyeti Tarihi I, İzmir 1984, s: 201.

41. İzzet Öztoprak, Türk ve Batı Kamuoyunda Millî Mücadele, Ankara 1989, s: 107.

42. a.g.e, s: $107-108$.

43. a.g.e, s: 151 .

44. a.g.e, s: 156.
} 
olduklarını, Osmanlı Hükümeti’ni muhatap alarak çözüme varılamayacağını görüyorlardı.

1921 yılının ilkbaharında Sovyetler'le olan ilişkiler de TBMM Hükümeti lehine gelişmişti; Sovyet basınında Türk milletinin gerçek temsilcisinin emperyalistlerin elinde oyuncak durumunda olan İstanbul Hükümeti değil, Mustafa Kemal'in başında bulunduğu Ankara Hükümeti olduğu yazıliyordu. ${ }^{45}$

20 Ekim 1921 Ankara Anlaşması da, Fransa'nın Ankara'yı, "Türkiye'nin sahib-i selâhiyet ve hakim hükümeti" olarak tanıdığını göstermektedir. ${ }^{46}$

Mustafa Kemal Paşa, bu anlaşmadan ve Fransız temsilcisi Franklen Bouillon'la yaptığı görüşmelerden bahsederken, "Eski Osmanlı İmparatorluğu'ndan yeni bir Türkiye Devleti vücuda gelmiştir. Bunu tanımak lâzımdır." demiştir. ${ }^{47}$ Aynı görüşmelerde Sevr Anlaşması hakkında da "Sevr Muahedesi, Türk milleti için o kadar meş’um bir idam kararnamesidir ki, onun bir dost ağzından çıkmamasını talep ederiz... Sevr Muahedesini, dimağından çıkarmayan milletlerle, itimat esasına müstenit muamelâta girişemeyiz. Bizim nazarımızda böyle bir muahede yoktur." demiştir. Neticede imzalanmış olan Ankara Anlaşması'yla millî politikalarımız ilk defa batılı bir devlet tarafından tanınmış oldu.

\section{C) Inkulâplar Dönemi}

Millî Mücadele'nin, TBMM'nin açılışına kadar süren hazırlık döneminin temel politikası Türk halkını bir mücadele azim ve kararlılığı etrafında toplamak olmuştur... Lozan Antlaşması'nın imzalanmasına kadar geçen dönemde ise Anadolu'ya yönelen işgal ve istilâya son vererek Misak-1 Millî doğrultusunda toprak bütünlüğünü sağlamak politikaları izlenmiştir. İnkılâplar dönemi veya kuruluş dönemi diyebileceğimiz üçüncü aşamada ise yeni Türkiye Devleti'nin, yeni temel değerler etrafında kurulduğu görülecektir: Mustafa Kemal Atatürk, Osmanlı Devleti'nin yıkıntıları arasından yeni, çağdaş bir Türk devleti yaratırken, Osmanlı teb'ası arasındaki Türk halkından da millî bir toplum yaratmış, onu tarihe ve dünyaya kabul ettirmiş, gelecekte de yaşayabilecek temeller üzerine yükselmiştir. Bu bakımdan Kemalizm/Atatürkçülük şöyle de tanımlanmıştır: "Kemalizm, varlığını koruyabilecek bir millî devleti kurma, vatandaşları bir siyasî millet haline sokma ve hem millî devletin ve hem de yaratılan siyasî milletin devamını sağlamaktır., ${ }^{, 8}$ Türk toplumunun derin tarihsel kökleri bu oluşumu güçlendirdi. Bu bakımdan devletin politikası, millî ve lâik toplum önündeki geçmişten intikal eden ve millî bütünlüğü engelleyici, zedeleyici,

\footnotetext{
45. a.g.e, s: 190.

46. a.g.e, s: 230.

47. Kemal Atatürk, a.g.e, s: 414.

48. İlter Turan, a.g.e, s: 75.
} 
zayıflatıcı unsurların giderilmesine, aksine millî bütünlüğü destekleyici unsurların güçlendirilmesine yönelmiştir.

Bir milletin siyasî manada var olması ve varlığını sürdürebilmesinin, yani bir devlet olarak yaşayabilmesinin şartlarından olarak kendisini aynı milletin üyesi sayan yeterli sayıda bir insan topluluğunun (beşerî unsurun) varlı̆̆ı, bu topluluğun üzerinde siyasî bir örgüt kurabileceği bir sahaya (coğrafî unsura) sahip olması ve bu topluluktaki bireylerin geleceklerini de aynı topluluğa bağlamaları aranır. ${ }^{49}$ Buna bir de otorite unsurunu ilâve edebiliriz; otoriteyi, toplulukta bulunan bireylerin, bulunduğu alan içinde itaat ve sadakat gösterecekleri yüksek irade olarak tanımlayabiliriz. Bu açılardan Osmanlı Devleti'nden yeni Türkiye devletinin doğuşu sürecine bakarsak:

I- a) Beşerî unsur; Osmanlı halkını temsil eden beşerî unsur, İmparatorluğa farklı zamanlarda katılmış, her biri ayrı etnik unsurlardı. Bu unsurlar kendi içlerinde dil, din ve inanç, gelenek birliğine sahip idiler. Ancak devlete vergi ödemek ve siyasî örgüt kurmamakla, başka bir ifade ile hanedana siyasî sadakat göstermekle yükümlüydüler. Dinî toplulukla devlet arasındaki temas topluluğun lideri aracılı̆̆ıyla kurulur ve topluluğun davranışlarından bu kişiler sorumlu tutulurlardı. "Osmanlı", devletin ve otoritenin adıydı; Devlet-i Âliye-i Osmaniyye, Memalik-i Mahrusa-i Osmanî, Tevarih-i Âli Osman, Kavanin-i Osmaniyan terimleri hep devlet ve hanedanla ilgiliydi. Millet ise "Tebâ-i Şahane"dir. Böyle bir toplum yapısı bir süre sonra Osmanlı Devleti için zaafiyet unsuru oldu ve bu sosyal yapı, 18. yüzyıldan itibaren dağılmayı hızlandırdı. Osmanlı İmparatorluğu, "etnik millet" anlamında bu topluluklardan, "siyasî millet" anlamında bir "Osmanlı milleti" yaratmak istemiştir; "İttihad-1 Milel-i Osmaniye" yaratmak politikaları başarılı olamamıştır. Bu beşeri yapının ortak zemini hanedana itaat ve sadakat olacaktı. Fakat Osmanlı toplumunun "kimya"sı bu politikaya uyum gösteremedi. Aksine bu yapının ve yönetim biçiminin bir zayıflık unsuru olduğu görüldü.

"Garbta ve şarkta başka başka tabayi ve harse ve emele malik mütehalif unsurları cem eden bir devletin dahilî teşkilatı, elbette asılsız ve çürük olur." ${ }^{50}$ : Mustafa Kemal Atatürk, bu eleştiriyle Osmanlı toplum yapısının zaafiyetine işaret ediyor.. "Muhtelif milletleri, müşterek ve umumî bir ünvan altında cem etmek ve bu muhtelif unsur kütleleri aymı hukuk ve şerait altında bulundurarak kavi bir devlet tesis etmek parlak ve cazip bir nokta-1 nazar-1 siyasîdir. Fakat aldatıcıdır." ${ }^{\text {"5l }}$ diyen Atatürk son dönem Osmanlı tarihinden çıkardığı tecrübeyle kendilerinin izleyeceği siyasetin "millî siyaset" olduğunu belirtiyor ve bu siyaseti şöyle tarif ediyor: "Hudud-1 milliyemiz dahilinde, her şeyden evvel kendi kuvvetimize müsteniden muhafaza-i mevcudiyet ederek millet ve memleketin hakikî saadet ve umranına

49. a.g.e, s: 12.

50. Kemal Atatürk, a.g.e, s: 291.

51. a.g.e, s: 291. 
çalışmak." 52 Bu millî politika, "millî devlet", "millî toplum" olarak hayata geçirilecektir.

"Millî devlette vatandaşlar topluluğu millet ile eş anlamdadır, millî devlet ise var olan veya yaratılmak istenen milletin siyasî örgütünü temsil eder." ${ }^{53}$ ve millet bir "vatan" üzerinde millî devletini kurar. Osmanlı geleneğindeki "Teb'a-i Şahane", "Millet-i Osmaniye" ki, Abdullah Cevdet bu tâbirin “İbad-1 Osmaniye (Osmanlı'nın kulları) demekle eşit olduğunu vurguluyor, bu topluluğun "millet"e dönüştüğü görülecektir; "milletin, varlığını devam ettirmesi için fertleri arasında düşündüğü müşterek bağ, asırlardan beri gelen şekil ve mahiyetini değiştirmiş, yani millet dinî ve mezhebî bağlantı yerine

Türk milliyeti bağı ile fertleri toplamıştır." ${ }^{.54}$

Osmanlı dilinde "millet" kelimesi varsa da anlamı günümüzdekinden çok farklıydı; kişilerin din ve inançlarına göre statülerinin belirlendiğini ve kendi dinsel topluluklarının liderine bağlı olduklarını belirtmiştik... Kişiler bu statüleriyle ülkenin her yerinde yaşayabilirdi; "Daha sonra Hristiyan teb'a arasında millîyetçi hareketlerin çok kolay ve çabuk örgütlenebilmesinin önemli bir nedeni, ayrı kimliklerin zaten kurumsallaştııılmış olmasıdır." 55

"Millet" kavramını, Fransızca'daki anlamına en yakın olarak kullanan, 1830 yıllarında Sâdık Rıfat Paşa olmuştur. II. Mahmut döneminde ve Gülhane Hatt-1 Hümayunu'nda da bu anlama yakın manada kullanılmıştır. $\mathrm{Bu}$ ifadelerde açıkça söylenmemekle beraber millî bir birlik arzulanmakta idi. Bununla beraber Tanzimat ve Meşrutiyet dönemlerinde "dinsel toplum" etkisinden kurtulunamamıştır: II. Mahmut döneminde Avrupa'ya Türk öğrenciler gönderilir. Paris'te bir kütüphanede çalışan Türk öğrencilerine kütüphane memurlarından bir tanesi milliyetlerini sorar. Öğrenciler "Müslüman" diye cevap verir. O sizin dininiz, milliyetiniz değil, der. Bunun üzerine "Osmanlıyız" derler. O sizin tâbiyetiniz cevabını alınca biraz durakladıktan sonra "Türk" olduklarına karar verirler." ${ }^{, 56}$ Ancak, I. Dünya Savaşı sonunda Anadolu'da oldukça mütecanis bir Türk topluluğu doğmuş, bu etnik toplulukda Türk millî devletinin temelini teşkil etmiştir.

b) Toprak (Coğrafî unsur): Osmanlıda, "toprak (ülke)" kavramı fetih gücüyle ilgiliydi; askerî bakımdan güçlü olunduğunda topraklar genişlemiş, zayıflayınca topraklar kaybedilmiştir: "Toprak devletin otoritesini kurabildiği yer anlamına geliyordu." ${ }^{, 57}$ Avrupa'da kullanılan "patrie" karşılı̆̆ "vatan"ın kapsamı daha farklıydı; millet bir "vatan" üzerinde millî devleti kurabilir. Millî devlet, "vatan"ı millî sınırlar içinde kalan topraklar diye

52. a.g.e, s: 292 .

53. İlter Turan, a.g.e, s: 13.

54. Utkan Kocatürk, a.g.e, s: 87.

55. İlter Turan, a.g.e, s: 38 .

56. a.g.e, s: 30 .

57. a.g.e, s: 93 . 
tanımlıyor ve bu anlayışın yaygınlaşmasını istiyordu; "Memaliki Mahrusa-i Osmaniye"nin, "vatan"a dönüşmesi politikası izlenecektir.

Osmanlı'da "vatan" kavramı varsa da, bu kavramla insanlar doğdukları yeri anlatırlardı. Namık Kemal ile birlikte "vatan sözü toprağa ek olarak, toprak üzerinde yaşayanlarla da ilgilenmeye başladı. Namık Kemal'e göre "vatan", sınırları bir fatihin kılıcıyla çizilmiş bir alandan ibaret değildi" çeşitli asil duyguların birleşmesinden ortaya çıkan bir varlıktı. Bu duygular arasında hürriyet, kardeşlik, egemenlik, atalara saygı, aileye sevgi, çocukluk anıları yer alıyordu."

Meşrutiyet dönemlerinde bir vatanseverlik duygusu işlenmiş, Genç Türkler arasında "vatan" kavramı doğum yeri gibi dar anlamdan daha geniş alanları anlatan anlamlara kadar kullanılmıştır. Türkçülük hareketi sırasında anlamı “Turan”1 kapsayacak kadar genişlemiş, 1917'de Sait Halim Paşa'nın sözlerinde şeriatın hüküm sürdügüü bütün ülkeleri anlatmıştır. Ancak Türkiye Cumhuriyeti'nin kurulmasıyla "vatan" sınırları belli ve millî devletin yaşama alanı olan topraklar olarak tanımlanmıştır.

c) Otorite (Egemenlik): Osmanlı geleneğinde yüksek egemenliği "Hanedan" temsil ediyordu; kişiler ve onların içinde yer aldıkları cemaatler padişaha sadakat göstermek zorundaydılar. Müslüman halk ise halifeye sadakat göstermekle yükümlüydüler: kişi, halifeye itaat ve sadakat göstermezse nasıl iyi bir Müslüman olabilirdi?

Millî Mücadele sürecinde, Saltanat bazı yetkilerinden yoksun bırakılmışsa da, 1 Kasım 1922'ye kadar varlığını sürdürmüştür. Yani Anadolu'da siyaseten iki başlılık yaşanmıştır. Bu iki başlılık, İtilâf Devletleri'nin Lozan görüşmelerine Osmanlı Hükümeti'ni de çağırmaları üzerine kendiliğinden çözülmüştür. Fakat Saltanat ve Hilâfet birbirinden ayrılmış, Saltanat kaldırıldığı için, Hilâfet kurumu durmaktaydı. Osmanlı geleneğinde padişah ve halife aynı kişiydi ve siyasî ve dinî görevler arasında da bir ayrım yapılmamıştı. Saltanat kalktıktan sonra da Halife'nin yetkilerinin ne olacağı hususunda bir tespit yapılmamıştı. Bu karışıklık otorite bunalımına yol açıyor, Halifelik'in siyasî iktidar demek olduğu, Meclis'in tabiî başkanının halife olduğu, "Devletin kanunları ve hükümetin kararlarının Halife tarafından tasdik edilmesi gerektiği söylenip, yazılıyordu." ${ }^{59}$ Geleneksel siyaset taraftarları Halife'nin etrafında siyaset yapmaya başlamışlar ve Halife'nin siyasal bir rakip teşkil edeceği anlaşılmıştı.

Hilâfet din adına kendisine sadakat istiyor, millî devlet ise en yüksek siyasal değer saydığı millî hakimiyet ilkesine ve onun tecelli ettiği kurum olan TBMM'ye itaat ve sadakat istiyordu; 3 Mart 1924'de Hilâfetin

58. a.g.e, s: 37

59. a.g.e, $\mathrm{s}: 78$. 
kaldırılması ve hanedan üyelerinin Türkiye'den ayrılması suretiyle, siyasî otoritede tartışılmaz bir teklik sağlanmıştır.

\section{II - "Millî Devlet" politikalarının uygulanması}

"Millî devlet" sınırları içinde tam hakimiyete sahip olmak ister, bunun gerçekleşmesi ise millî devlet olması istenen toplumun ekonomik, askerî, kültürel gücüne bağlıdır. Mustafa Kemal Atatürk, "Onuncu Yıl Nutku"nda, "Az zamanda çok ve büyük işler yaptık, bu işlerin en büyügüu, temeli Türk kahramanlığı ve yüksek Türk kültürü olan Türkiye Cumhuriyeti'dir." demiștir. Millî devletin adı, parası, bayrağı, meclisi, insanı, kültürü, ülkesi, dili hep "Türk" ve "Türkiye" adıyla adlandırılmıştır. Öyleyse devletin "millî" kimliği üzerinde şüphe yoktur; bu "Türklük" inancıdır... Bu inanç "vatan" ve "millet" kavramlarının korunmasıyla güçlendirilmelidir. Millî devlet korunmak isteniyorsa bu, korumayı amaç edinmiş politikaları izlemekle olur. Yani millî devlet de vatandaşlarından itaat, fedakârlık ve sonsuz sadakat bekler. Bu nedenle insandan sonsuz sadakat ve fedakârlık bekleyen kurumlar (hilâfet, tekkeler, tarikatlar...) siyasî hayatın dışına çıkarılmışlardır. Vatandaşların siyasî hayata millî bir çerçeve içinde katılmaları ön plana alınmıștır. Bu sebepten millî devlet politikaları millîyetçi ve lâik özellikler göstermiştir: Yeni Türkiye Devleti'nin kuruluş dönemindeki "Atatürk İnkılâpları" böyle bir çabanın ve politikanın ürünüdür.

Millî devletin kendisine rakip olabilecek kurum ve unsurları ortadan kaldırması, siyasî hayatın dışına çıkarmaya çalışması, eğitimin birleştirilerek Maarif Vekâletine bağlanması, enternasyonalist (komünizm gibi..) akımlara karşı çıkılması, hukuk, kültür, kıyafet alanlarında izlenen lâiklik politikaları yeni bir devlet ve toplum yapısı kurmaya yöneliktir.

$\mathrm{Bu}$ politikalara en büyük katkı eğitim alanında yapılan reformlardır. Bu uygulamalar bir siyasal ve toplumsal zihniyet değişimine yol açmakta ve yeni yönetim biçimine sadakatı ve milletine güveni telkin etmektedir; Osmanlı Devleti'nin son devrelerinde uğradığı yenilgiler ve I. Dünya Savaşı yenilgisi Türk milleti'nin kendine duyduğu güvenin sarsılmasına yol açmıştı. Sosyal ve kültürel alandaki inkılâplarla, Türklerin ileri bir toplum kurabileceklerine dair bir inanç yaratmanın zorunluluk olduğu görülmüştür. $\mathrm{Bu}$ anlayış eğitim-öğretime yansıtıldığı gibi aynı zamanda da kurumlaştırılmıştır. Yeni bir tarih tezi ileri sürülmüştür; "Bu teze göre medeniyetin ilk kurucuları Orta Asya'daki Türklerdi. Türkler Orta Asya'dan göç ederek medeniyeti dünyanın diğer bölgelerine yaymışlardı. Bugünkü Avrupa medeniyetinin öncüleri de Türklerdi. O halde Türklerin batılılaşmak istemesi, doğmasında kendilerinin büyük payı olan bir uygarlığa tekrar dönmelerinden ibaretti. Yani tarih tezi iki psikolojik ihtiyaca cevap verdi. Bir kere, eğer Türkler geçmişte bu kadar büyük bir medeniyete sahip idi iseler gelecekte de büyük bir medeniyet kurabileceklerine güvenebilirlerdi. Sonra Avrupa medeniyetine katkıları büyük olduğundan Avrupa karşısında 
bir aşağılık duygusuna kapılmalarına sebep yoktu. Batılılaşmak demek, kendilerinin de bir parçası olduğu uygarlığı yeniden benimsemek demekti. ${ }^{, 60}$ İkinci olarak, Anadolu'nun dip tarih araştırmalarına yönelinmiştir. Bu yönelimde lâik düşüncenin etkisi olduğu da düşünülebilir. Aynı zamanda millî toplum politikalarına da bir katkıdır. Böylece, "Yeni milletin üyelerine geçmişlerinin bir olduğu ve geleceklerinin de bir olacağı, Türklerin yurdunun Anadolu olduğu anlatılmak istenmiş̧tir. ${ }^{61}$ Osmanlı ortadan kalktığı için doğan "geçmiş boşluğu" böylece doldurulmaya çalışılmıştır.

Dil ve harf inkılâbı da millî devlet-millî toplum politikalarının bir parçasıdır. Dilde Türkçecilik akımının Osmanlıdan gelen bir geçmişi de vardır. Dil, millî bütünlügüü önemli bir faktörüdür. Bu inkılâpta da, diğerlerinde olduğu gibi itici güç Türk milliyetçiliği ve bundan ilham alan millî ve lâik düşünceler olmuştur.

Güneş-Dil Teorisi'nin ortaya atılmasının nedenlerinden biri de, "Türklerin zengin bir dile sahip oldukları, Türk kültürünün diğer kültürlerden zayıf olmadığg gösterilerek, özellikle gençlerin kendilerine güvenmeleri ve Türklükle iftihar etmelerinin sağlanması..." idi. ${ }^{62}$ Bir maksat da, "Arap dünyasının kültürel hegemonya"sından kurtulmaktı.

Harf inkılâbının millî bütünleşmeye katkıları da şu noktalarda toplanmaktadır: ${ }^{63}$ Kısa sürede okuma yazma oranı artırılarak hitap edilen halk kitlesi genişlemiş, millî değer ve amaçların yaygınlaşması kolaylaşmıştır. Arap kültürü ile irtibat zayıflamış, dinin politik bir güç olarak kullanılma imkânı azalmış, millî toplum kavramı güçlendirilmiştir. Özellikle örgün öğretimde yeni yönetimin temel değerlerinin halka ulaştırılması kolaylaşmıştır. Bu bakımdan Atatürk yeni harflerle okuma yazma öğrenmeyi, öğretmeyi en büyük vatanseverlik ve milliyetçilik görevi olarak övmüştür. ${ }^{64}$

Millî devleti kurma ve güçlendirme politikalarının bir yönü de halkı siyasî hayata iştirak ettirmek ve halkı millî hayatın bir parçası yapabilmektir. Atatürk bu ilkeyi daima gözetmiş, "Millî hakimiyet"i en üstün siyasal değer olarak tutmuştur. Böylece, millî devletin "demokratik" olma özelliği ortaya çıkmıştır. Kadınlara seçme ve seçilme hakkının verilmesi, millî iradenin tamamlanmasını sağlamıştır. Çok partili siyasî hayata geçilmiş, iki defa muhalefet partisi kurulmuşsa da geleneksel teokratik / ümmetçi politikaların etkisiyle demokratik mücadele ve yarış bir rejim mücadelesine dönüşme istidatını gösterdiğinden başarılı olunamamıştır... Bu uygulamalar geleneksel

\footnotetext{
60. a.g.e, s: 55 .

61. a.g.e, s: 57.

62. a.g.e, s: 58 .

63. a.g.e, s: $91-92$.

64. Utkan Kocatürk, a.g.e, s: 146.
} 
politika taraflarınca yeni yönetimin otorite zaafı olarak yorumlanmış, ancak 1946'dan sonra devamlı bir uygulama görülebilmiştir.

Millî Mücadele'nin askerî ve diplomatik bir zaferle sonuçlanmasından sonra yeni Türkiye devletinin dayandığı temel değerleri esas alan bir siyasal hareket olarak Cumhuriyet Halk Partisi'nin kurulduğu görülmüştür. ${ }^{65}$ Mustafa Kemal Paşa, bir millet ferdi sıfatıyla hayatını sonuna kadar vatana hizmet yoluna adamak için böyle bir yola yöneldiğini, partinin başka ülkelerde olduğu gibi herhangi bir sosyal sınıfın çıkarlarını korumak için değil, bütün milleti kucaklayacağını belirtmektedir. 8 Nisan 1923'te yayımlanan ve yeni partinin ilkeleri olan "Dokuz umde"de millî hakimiyete özellikle vurgu yapılmakta ve Türkiye'yi çağdaş bir devlet haline getirme hedefi ortaya konmakta idi.

Uygulamada görülen parti-devlet politikasıyla, yeni Türk devletinin temel siyasî değerlerinin parti ve parti organları vasıtasıyla halka yayılması ve memleketin her köşesine ulaştırılması politikaları izlenmiştir. Bu hususta Halkevleri ve Halkodaları önemli görevler yapmışlardır... Bu kurumların yapılanışları ve faaliyetleri incelenirse, çalışmaların millî ve lâik toplum hedefine yönelik olduğu görülür...

Halkın siyasal ve toplumsal hayata katılımı hiçbir ayırımı kabul etmeyeceğinden millî devletin politikaları "demokratik" ve "millı̂" olmanın yanı sıra "lâik" olmak zorundadır; millî devletin vatandaşlarından en yüksek fedakârlık ve sadakatı beklediğini, bunu isteyen diğer kurumları siyasî hayatın dışına çıkardığını belirtmiştik... Bu bakımdan Hilafetin kaldırılmasının ardından Evkaf ve Şeriyye Vekâleti'nin kaldırıldığı, medreselere son verildiği, tekke ve zaviyelerin kapatıldığı görülmüştür; "Dinin tefsirlerindeki ayrılıklardan dolayı veya dinin sosyal bünyeye uygulanmasını temin için kurulan tarikatler ve tarikatlerin toplanma merkezi olan tekkeler, üyelerinden en yüksek sadakatlerini talep ettiklerinden ve bazı hallerde siyasî otoritenin kararlarını tanımadıklarından, topluma iktisadî bir katkıları bulunmadığından, rasyonellik yerine mistisizmi tercih ettiklerinden gerek vatandaşlar arasında derin bölünmelere yol açmış, gerek devlet otoritesini zayıflatıcı bir rol oynamışlardır." ${ }^{, 66}$ İnkılâp kanunlarıyla yapılan düzenlemelerle bu kurumların kapatılması suretiyle devlet otoritesini zayıflatıcı sosyal bir etken de ortadan kaldırılmış oluyordu. Fertlerin "cemaat" şuuru yerine "millîyet" şuuru etrafında bütünleşmesinin önü açılmış oluyordu. Dinsel otoriteyi temsil ettiği iddiasında bulunan kişilerin ve çevrelerin siyasal etkinliği kırılıyor ve otorite bütünlügüne katkıda bulunuluyordu.

65. Tuncay Dursun, Tek Parti Döneminde Cumhuriyet Halk Partisi Büyük Kurultaylart, Ankara 2002, s: 5-10.

66. İlter Turan, a.g.e, s: 82. 
Kılık kıyafet alanında yasalarla yapılan düzenlemeler de, yukarıdaki uygulamaları tamamlar niteliktedir: "Osmanlı Devleti'nden tevarüs edilen sosyal sistemde giyim sosyal ve dinî farklılaşmaları kuvvetlendirici nitelikteydi." ${ }^{, 67}$ Fertlerin siyasal ve dinsel tercihlerinin dişa vurumu olan bu durum sosyal kaynaşmayı önlemekte, millî bir topluma aidiyet duygusunu bölmekteydi. Halbuki yeni Türk devleti cemaat esasına değil, eşitlik üzerine kurulmuş vatandaşlık anlayışına dayanıyordu ve giyimin sosyal bir ayırım amacı olarak kalmasını gelişmeyi önleyici ve bölücü olarak görüyordu.

Dinî hizmetle görevli olanların, dinî kıyafetlerini yalnızca ibadet sırasında ve görev yerinde giymeleri mecburiyetinin yasayla düzenlenmesinin amacı da, dinsel bakımdan sosyal bir tabakanın yaratılmasının önüne geçmekti; dinî hizmetle görevli olanların ibadethane dışında da "saygı ve otorite" talep etmelerinin, hatta dinsel görevi olmayanların da bu kıyafetlere bürünerek halktan saygı, itaat ve malî yardım beklemeleri önlenerek sosyal ayrışma nedenlerinden biri daha ortadan kaldırılmak istenmiştir.

Osmanlı yönetimi sırasındaki uygulamalarda İslâmlaşmakla Araplaşmak özdeş hâle gelmişti: Bu sosyal reformlar Türkiye'yi Arabî bir Asya toplumu olmaktan çıkararak lâik - Batı medeniyet dairesine yönelten politikalardır: Bu uygulamalar "Batılılaşma"nın psikolojik ortamını da hazırlamıştır. Böylece toplumsal ilişkiler lâik ve millî esaslar üzerine kurulmuştur... Bu yapılanma bir anda olamazdı ama, "geleceğin ne yönde olacağına dair" güçlü işaretlerdi.

Biçimsel gibi görünen bu inkılâp uygulamalarının zihinsel yanını da görmemek olmaz; böylece fert, vatandaşlar topluluğunun bir üyesi yapılmış, iradesi özgürleştirilmiş, vatandaşa kendi aklını bir başkasının klavuzluğu olmadan, onun vesayeti altına girmeden kullanma yeteneği kazandırılmak istenmiştir. Böylece "millî hakimiyet", hür irade ile tecelli edebilecekti.

17 Şubat 1926 'da Türk Medenî Kanunu çıkarılmış, Borçlar, Ceza ve Ticaret Hukuku alanlarında da Batı hukuku örneklerinden tercüme yoluyla haklar alanında lâik düzenlemelere gidilmiştir.

Yeni Türkiye devleti ekonomik sorunlarının çözümünde ideolojik düşünmemiştir: Ülkenin kalkınmasında ekonominin önemi sık sık vurgulanırken yine "bağımsızlık", "vatanseverlik" temalarının işlendiği görülmektedir. Kapitülâsyonların kötü hatıraları toplumda bağımsızlık duygusunu güçlendirmişti... Bağımsızlık, vatanseverlik, fedakârlık, çalışkanlık duygularıyla güçlendirilmiş bir gönül seferberliği başlatılmıştır... $\mathrm{Bu}$ anlayış "millî ekonomi" diye adlandırılmıştır:

67. a.g.e.s: 83 . 
“... Türkiye'nin hür, bağımsız, daima daha kuvvetli, daima daha refahlı Türkiye idealinin" bel kemiği olarak ekonomik kalkınma görülmüştür. ${ }^{6.8}$ İzmir İktisat Kongresi'nde (17 Şubat - 4 Mart 1923) belirlenen "Misak-1 İktisadî Esasları"nda da, "Türkiye, millî hudutları dahilinde lekesiz bir istiklâl ile dünyanın sulh ve terakki unsurlarından biridir." denildikten sonra Türk halkının çalışkan olduğu, birlik içinde bulunduğu, ülkesini imâr etmek ve kalkınmak emelinde olduğu belirtilmiştir. ${ }^{(x)}$ Gerçekten böyle bir hedefe, ülkenin bütününü "vatanım", halkın tamamını "milletim" diye kucaklamayan bir zihniyetle varılabilir miydi? Bu bakımdan iktisadî politikalar da, millî bütünleşmeye katkı istikâmetinde izlenmiştir. Kalkınma, fertlerin yeni rejime güvenini ve bağ lılığını artıracak, vatandaşlar arasında haberleşme ve etkileșimin artması da kaynaşmaya büyük katkıda bulunacaktı... Bu nedenlerle de ulaştırma politikalarına ağılık verilmiştir.

Millî - toplumsal bütünleșmeyi kolaylaștıran faktörlerden biri de millî semboller ve bayramlardır: "Millî devlet kurulduktan sonra kendisine özgü semboller yaratarak, bayramlar ihdas ederek vatandaşların sadakâtini hissî olarak da kendine bağlamak ister."70 Bu bakımdan henüz Millî Mücadele sürerken İstiklâl Marşı'nın kabul edilmesi, kuruluş döneminde ve daha sonra çeşitli törenlerde söylenmesi vatan, millet, bağımsılık fikirlerini güçlendirmiştir. Bayramlar da aynı amaca yöneliktir. Böyle günlerde yapılan büyük kutlamalar bu hisleri güçlendirdiği gibi sadakât duygularını da pekiştirir; "Bayramların ithaf edildiği topluluklara bakacak olursak, bunlar millî rejimin kısa ve uzun dönemde idamesini sağlayacak olanlardı. 30 Ağustos Orduya, 23 Nisan Çocuklara, 19 Mayıs Gençlere verilmiş ve bu günlerde yapılan törenlerde onların millî devlete duydukları bağların kuvvetlendirilmesine çalışılmıștır. 29 Ekim ise bütün vatandaşlara yönelmiştir."

\section{SONUÇ}

I. Dünya Savaşı sonunda kurulan Türkiye Cumhuriyeti, Osmanlı İmparatorluğu'ndan önemli ayrılıklar göstermekle beraber, tarihî bir boşlukta doğmuş değildir; Osmanlı döneminde yaşanan fikrî, siyasî, askerî ve ekonomik tecrübeler, yeni devletin kuruluş aşamasında ve temel siyasal değerlerinin oluşmasında önemli bir yer tutar; bu oluşumda Türk milliyetçiliği fikrinden kaynaklanan "millî hakimiyet" ilkesi belirleyici olmuştur. Atatürk'ün ifadesiyle yeni Türkiye Cumhuriyeti’nin yapısının ruhu millî egemenliktir." ${ }^{72} \mathrm{Bu}$ ilkenin devlet ve toplum hayatında yürürlüğe konmasıyla millî, demokratik, lâik bir devlet ve toplum yapısı oluşmuştur. Böylece yeni Türkiye devletinin varlık sebebi olan temel siyasi değerleri

68. Utkan Kocatürk. a.g.e, s: 298.

69. A. Afet Inan. Izmir Iktisat Kongresi, Ankara 1989. s: 19-20.

70. Ilter Turan, a.g.e, s: 118 .

71. a.g.e.s: 118 .

72. Utkan Kocatürk. a.g.e. s: 34. 
ortaya çıkmıştır. Böyle bir değişimin mutlaka askerî şartlarla birlikte olması gerekmez. Ama, bu büyük siyasal değişim, paralelinde bir askerî zaferle gerçekleşmiștir. Bu bakımdan Mustafa Kemal Atatürk, bu askerî zaferin Başkomutanı olduğu gibi, yeni Türkiye devletinin de siyasî mimarıdır: $\mathrm{O}$, Osmanlı'nın çöküşünü gördükten sonra yeni Türkiye Devleti'ni, çok kültürlü bir yapı üzerine değil, Türk kültürü ve toplumu üzerine siyasî bir kurumlaşma ile yapılandırmıștır; farklılıkları kurumlaștırma yerine, zaten var olan büyük ölçüdeki ortak noktalar kurumlaştırılmıştır. Böylece millî-üniter bir devlet yapısı ortaya çıkmış ve mevcut imkânlarla modernleşme, kalkınma ve ekonomik büyüme politikalarına yönelinmiștir. Yeni Türkiye devletinin gerek millî mücadele döneminde ve bu dönemin askerî ve politik cephesinde, gerekse inkılâplar döneminde Atatürk'ün yönlendirici ve belirleyici rolü çok açıktır.

Mustafa Kemal Atatürk, etrafındaki ülkelerin gayri resmî de olsa Türkiye'ye yönelik saldırgan politikalarına rağmen, Türk milletinin, bağımsız bir devlet ve vatan edinmesini sağlayarak, ona yeni bir Türk devleti ideali ve millet bilinci vermiştir. Millî devlet, vatandaşlarına bir millî hayatın parçası oldukları, bu hayatın devam etmesinin bütün toplumun yararına olduğu bilincini yaygınlaştırma politikası izlemiştir. Millî hayatı ve birliği sürdürme iradesi ne kadar güçlü olursa iç ve dıș sorunlara karşı toplumun dayanma gücü de o kadar artacaktır. Bu manada Türkiye Cumhuriyeti'nin temel siyasal değerlerine ve bu değerlerin somut tecellisi olan Mustafa Kemal Atatürk'e saygı ve sadakatın sürmesi, bu yolda aydınlatma ve bilgilendirme çabaları ulusal ve uluslar arası düzeyde varlığımızın sürmesinin önemli bir şartı olmuştur.

Atatürk'ün, geçmișe derinliğine bakan bir tarihçi, ileri görüşü bir devlet adamı olarak kurduğu bu siyasal düzen, bugün de hâlâ model olma özelliğini korumaktadır; onun kurulmasına önderlik ettiği millî - lâik - demokratik devlet ve toplum yapısı yerine, bir an için, teokratik - monarşinin sürdügüüu sosyal ve siyasal inkılâpların yapılmadığı ve doğal olarak Sevr'in belirlediği bir siyasal tarih çizgisinde 21. yüzyllın Anadolu ve Orta - Doğu'sunun ne hale geleceğini, Anadolu'nun nasıl Balkanlaşacağını düșünebiliyor muyuz?

\section{KAYNAKÇA}

1- A. Afet İnan, Izmir İktisat Kongresi, Ankara 1989.

2- Afif Büyüktuğrul, 18 Mart Çanakkale Zaferi ve Atatürk, Milliyet Gazetesi, 18 Mart 1974.

3- "Atatürk", md, İslâm Ansiklopedisi, C: I.

4- Bayram Kodaman, Cumhuriyetin tarihî - fikrî temelleri ve Atatürk, Isparta 2001.

5- Bekir Sitkı Baykal (Yay.Haz.), Erzurum Kongresiyle ilgili belgeler, Ankara 1969,

6- Bernard Lewis, Modern Türkive'nin Doğuşu, Ankara 1984. 
7- Cemalettin Taşkıran, Millî Mücadele'de Kâzım Karabekir Paşa, Ankara 1999.

8- Enver Ziya Karal, Osmanlı Tarihi, VII. Cilt, Ankara 1977.

Osmanlı Tarihi, VIII. Cilt, Ankara 1962.

Atatürk'ten Dïşünceler, İstanbul 1981.

9- Ergün Aybars, Türkiye Cumhuriyeti Tarihi I, İzmir 1984.

10- İlter Turan, Cumhuriyet Tarihimiz, İstanbul 1969.

11- İzzet Öztoprak, Türk ve Batı Kamuoyunda Millî Mücadele, Ankara 1989.

12- Kemal Atatürk, Nutuk (1919 - 1927), Ankara 1989.

Nutuk - Vesikalar, Ankara 1991, Vsk: 26.

13- Mazhar Müfit Kansu, Erzurum'dan ölümüne kadar Atatürkle beraber, 1. Cilt, Ankara 1986.

14- Tarık Zafer Tunaya, Türkiye'de Siyasal Partiler, C: I (İkinci Meşrutiyet Dönemi) İstanbul 1984.

15- Tuncay Dursun, Tek Parti Döneminde Cumhuriyet Halk Partisi Büyük Kurultaylart, Ankara 2002.

16- Uluğ İğdemir, Sivas Kongresi Tutanakları, Ankara 1986.

17- Utkan Kocatürk, Atatürk'ün Fikir ve Düşünceleri, Ankara 1999.

18- Yahya Akyüz ve diğerleri, Atatürk İlkeleri ve Inkılâp Tarihi I/1, Ankara 1997. 


\section{EKLER}

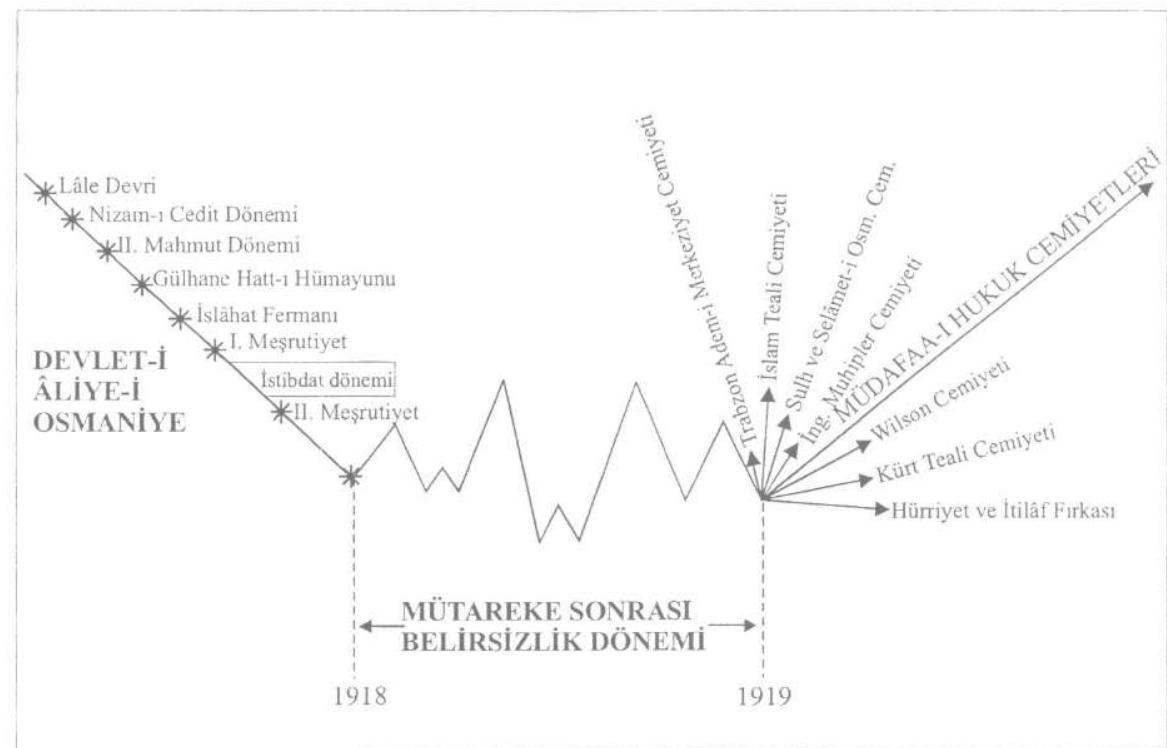

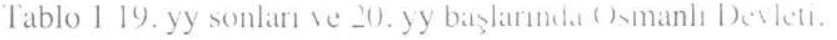

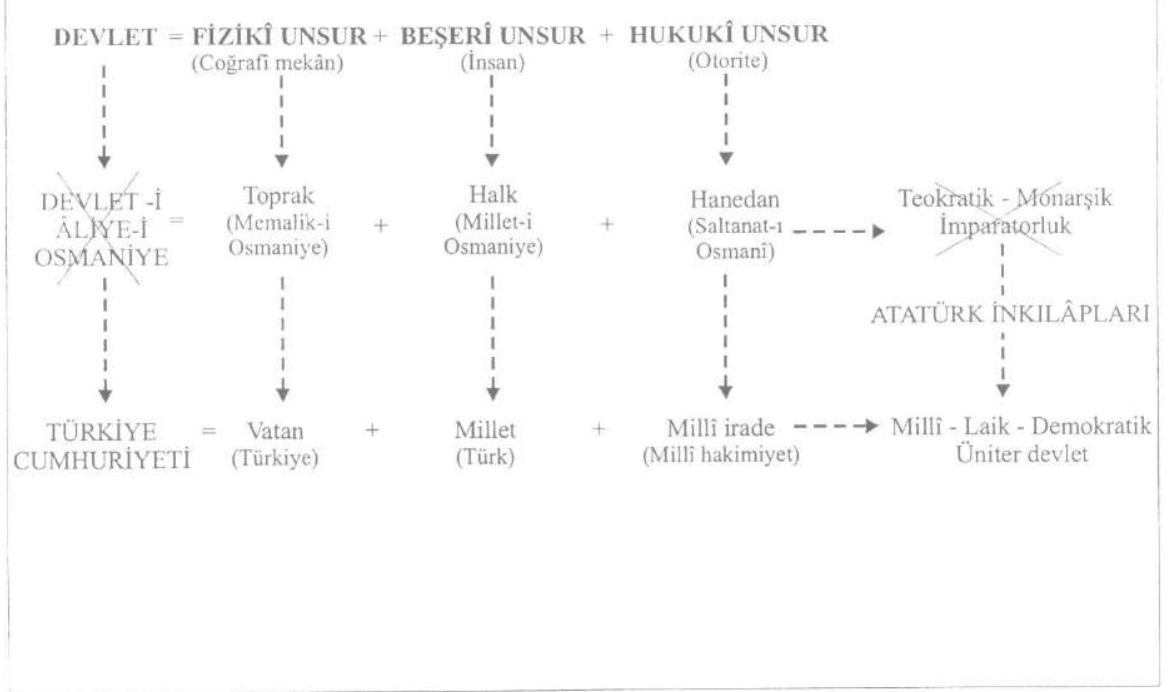

Tablo 2: Devletin temel değgerlerindeki değişim. 


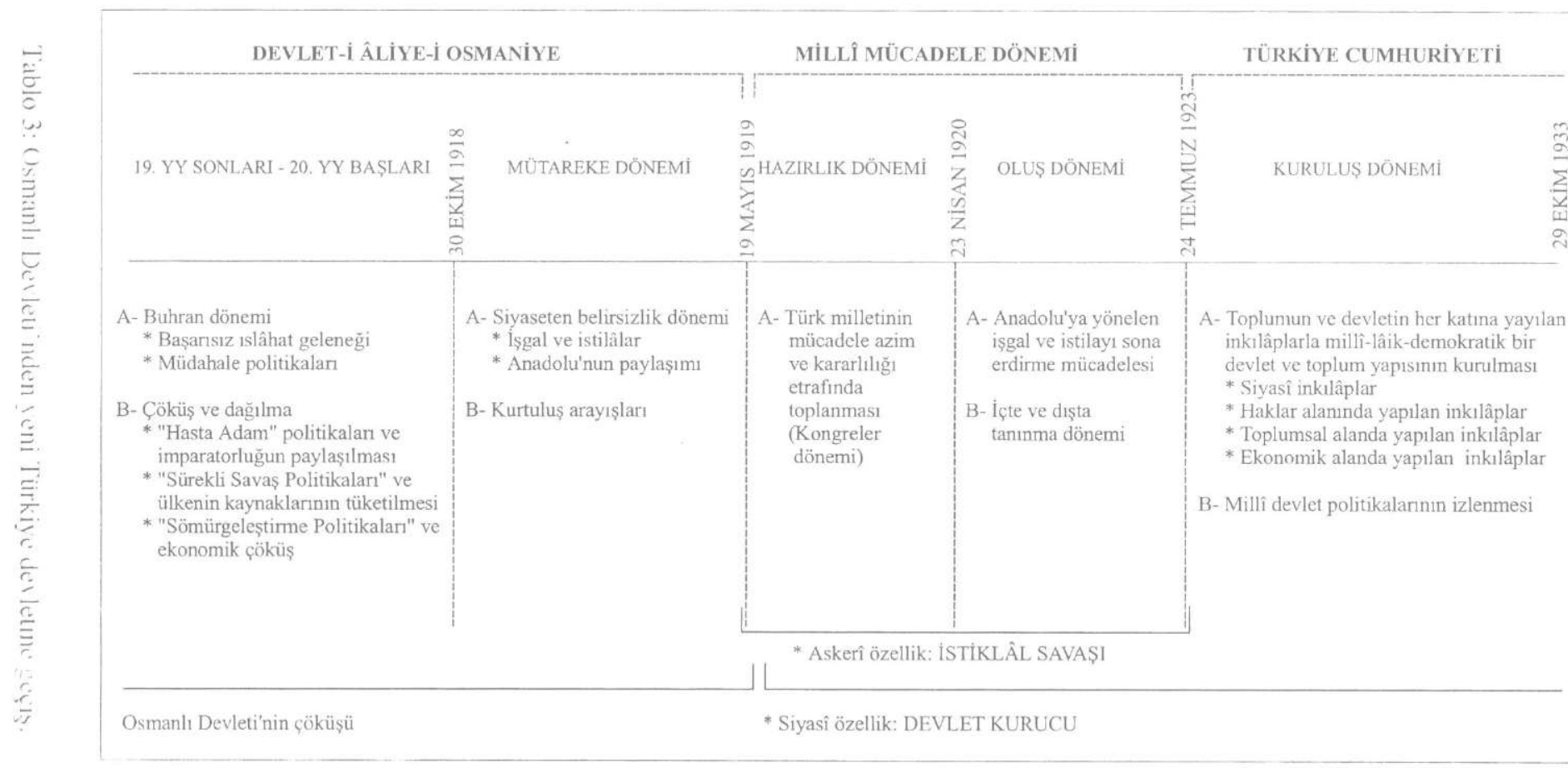

